\title{
Dostupnost socijalnog kapitala prilikom traženja prvog zaposlenja diplomanata različitog socioekonomskog statusa
}

\author{
IVONA ČARAPINA ZOVKO* \\ Filozofski fakultet \\ Sveučilište u Mostaru \\ Mostar, Bosna i Hercegovina
}

\author{
Izvorni znanstveni rad \\ UDK: $330.14: 331.103 .1$ \\ doi: 10.3935/rsp.v25i2.1501 \\ Primljeno: rujan 2017.
}

\section{DARJA MASLIĆ SERŠIĆ}

Odsjek za psihologiju

Filozofski fakultet Sveučilišta u Zagrebu

Zagreb, Hrvatska

Cilj istraživanja bio je ispitati sociodemografske prediktore socijalnih mreža na koje se mogu osloniti diplomanti prilikom traženja prvog zaposlenja - procjenama njihove veličine, snage socijalnih veza i statusa aktera $u$ mreži. Veličina mreže definirana je kao ukupan broj ljudi s kojima je pojedinac povezan, a snaga veze kao bliskost društvenog odnosa između pojedinca $i$ druge osobe u mreži. Bliski prijatelji i rođaci su primjer snažnih veza, dok rijetko kontaktirani poznanici predstavljaju slabe veze koje su socijalno, emocionalno i često fizički udaljene. Status aktera operacionalizira se kao obrazovni, radni i ekonomski status onih koji čine mrežu pojedinca. Istraživanje je provedeno na prigodnom uzorku od 730 diplomanata javnih fakulteta u Bosni i Hercegovini. Podaci su prikupljeni online anketom i temelje se na samoprocjenama. Utvrđeno je da socioekonomski status pojedinca predviđa njegovu procjenu vlastite socijalne mrě̌e: prosječna materijalna primanja pozitivan su samostalni prediktor veličine mrě̌e, a prosječna materijalna primanja $i$ zaposlenost oca pozitivan prediktor statusa aktera na koje se mogu osloniti diplomanti prilikom traženja prvog zaposlenja. Istraživane socioekonomske karakteristike diplomanata objašnjavaju između 2,8\% i 3,45 varijance individualnih razlika u doživljaju socijalnog kapitala. Ispitivane socioekonomske značajke diplomanata nisu bile povezane s doživljajem snage veza koje čine socijalnu mrežu.

Ključne riječi: diplomanti, socijalne mreže, socijalni kapital, socioekonomske značajke pojedinca, traženje posla.

* Ivona Čarapina Zovko, Filozofski fakultet, Sveučilište u Mostaru / The Faculty of Humanities and Social Sciences, University of Mostar, Matice hrvatske b.b. 88000 Mostar, Bosna i Hercegovina / Bosnia and Herzegovina, ivona.carapinazovko@ff.sum.ba 


\section{UVOD}

Zdravlje, financijski status, formalno obrazovanje, znanje i vještine, ali i radna motivacija te neke osobine, prediktori su karijernog uspjeha i zadovoljstva životom pojedinca. Radi se o individualnim resursima koje osoba koristi za uspješno suočavanje s različitim izazovima i zahtjevima s kojima se suočava tijekom života (Hobfoll, 1985.). Ovi resursi definiraju i ljudski kapital neke zajednice na temelju kojeg možemo predviđati ekonomski rast i društvenu dobrobit (Goldin, 2016.). Međutim, za uspjeh, kako na pojedinačnoj tako i na društvenoj razini, važan je i socijalni kapital - stupanj u kojem su pojedincu dostupni i resursi koje posjeduju drugi ljudi (Coleman, 1990.; Try, 2005.). Njega čine međusobne veze koje ljudi stvaraju kako bi ostvarili profesionalne ili osobne ciljeve, pa na individualnoj razini razlikujemo ljude u stupnju umreženosti ili izoliranosti, a na društvenoj razini, govorimo o fenomenima društvene mobilnosti ili segregacije. U ovom radu, bavimo se socijalnim kapitalom na individualnoj razini, a definiramo ga percepcijom veličine i karakteristika socijalne mreže koju pojedinac smatra dostupnom i korisnom u procesu traženja zaposlenja. Pritom su u središtu pažnje demografske odrednice socijalnog kapitala mladih u trenutku završavanja studija.

\section{Socijalne mreže kao mjera socijalnog kapitala pojedinca}

Jedan od načina na koji možemo utvrditi socijalni kapital pojedinca temelji se na prikupljanju samoprocjena o veličini socijalne mreže, snazi uspostavljenih veza i značajkama drugih s kojima smo povezani. Tako razlikujemo ljude po veličini, ali i karakteristikama socijalnog kapitala koji posjeduju. Dugotrajna je rasprava među istraživačima socijalnih mreža između for- malista koji naglašavaju važnost strukture mreže i supstancijalista koji naglašavaju sadržaj i sastav mreže (Borgatti i Foster, 2003.).

Prema formalistima, izvor društvenog kapitala nalazi se u formalnoj strukturi odnosa ili veza s drugima koji čine društvenu mrežu (Adler i Kwon, 2002.). Prvi važan element strukture mreže je veličina mreže ili ukupan broj ljudi s kojima je pojedinac povezan (Seibert, Kraimer i Liden, 2001.). Što je društvena mreža nekog pojedinca, primjerice, tražitelja posla, veća, on će vjerojatno prilikom traženja posla kontaktirati i veći broj drugih osoba. Struktura mreže općenito se odnosi na raspon veza u mreži, iskazan kroz broj socijalnih veza koji netko posjeduje, broj različitih statusnih skupina u nečijoj mreži (raznolikost mreže), udio kontakata koji su blisko povezani jedni s drugima te udio socijalnih veza sa osobama koje su slabo povezane s pojedincem. Što je veći raspon mreže, vjerojatnije je da će pojedinac dobiti informaciju relevantnu za statusni i drugi napredak (Campbell, Marsden i Hurlbert, 1986.).

Druga ključna komponenta strukture društvene mreže sastoji se od snage veza u mreži (Granovetter, 1973., 1995.). Snaga veze definira se kao bliskost društvenog odnosa između pojedinca i druge osobe u mreži (Granovetter, 1973.). Snaga veze ovisi o pet kriterija: duljini odnosa, emocionalnom intenzitetu, stupnju bliskosti, broju međusobno razmijenjenih usluga između članova i višestrukosti odnosa ( $\mathrm{tj}$. produktu razmjena). Bliski prijatelji ili rođaci su primjer snažnih veza, dok su poznanici koji rijetko kontaktiraju primjer slabe veze (Brown i Reingen, 1987.). Slabe veze su one koje su socijalno, emocionalno i često fizički udaljene (Marsden i Campbell, 1984.). Snažne veze su obično više dostupne nego slabe veze i rezultiraju češćim interakcijama, čime se povećava vjerojatnost 
dobivanja informacija (Reingen i Kernan, 1986.). U tom smislu, istraživanja su pokazala veću vjerojatnost oslanjanja na snažne veze prilikom prikupljanja informacija (Brown i Reingen, 1987.; Gilly, Graham, Wolfinbarger i Yale, 1998.).

Granovetter (1973., 1995.) je u istraživanjima o strategijama traženja posla ustanovio kako je većina stručnjaka i menadžera koje je intervjuirao do svog posla došla neformalnim putem, dobivajući informacije od svojih poznanika i kolega. To je opažanje uz prethodne spoznaje o socijalnim mrežama vodilo teoriji o snazi slabih veza, prema kojoj su upravo slabe društvene veze važne za karijerni uspjeh jer one premošćuju socijalni prostor između tražitelja posla i potencijalnih poslodavaca (Granovetter, 1973.). Takve su veze najučinkovitije ukoliko potječu iz profesionalnih krugova, ukoliko nemaju mnogo posrednika ili stupnjeva i ukoliko ne počivaju na osobnoj bliskosti. Snažne socijalne veze, poput rodbinskih ili prijateljskih, trebale bi biti manje relevantne za karijerno ponašanje jer se najčešće nalaze u neposrednoj, prostorno bliskoj, socijalno homogenoj i gusto premreženoj društvenoj sredini, tako da je količina novih informacija dobivenih kroz njih značajno manja. Drugim riječima, snažne socijalne veze ne premošćuju nego povezuju.

Nasuprot formalističkom naglasku na strukturi mreže, supstancijalisti su usredotočeni na resurse koji se razmjenjuju kroz društvene mreže i tvrde da učinci strukture veza u potpunosti ovise o sadržaju tih veza (Lin, 1999.). Sadržaj veza ili mrežni sastav odnosi se na karakteristike ljudi u pojedinčevoj socijalnoj mreži i odražava kvalitetu izvora, primjerice, informacija koje nude (Adler i Kwon, 2002.). Aquilera (2002.) je utvrdio značajno manju vjerojatnost primanja relevantnih informacija o mogućnosti zapošljavanja ako je nezaposlena osoba u kontaktu s nezaposlenom, nego zaposlenom osobom. Sastav mreže operacionalizira se kao obrazovni, profesionalni i ekonomski status onih koji čine mrežu pojedinca (Aguilera, 2002.; Hällsten, Adling i Rydgren, 2016.; Mouw, 2003.; Reingold, 1999.). Dakle, sastav mreže opisuju njeni akteri, odnosno pojedinci koji ju čine. Sukladno tome, većim socijalnim kapitalom smatra se ona mreža čiji sastav čine osobe višeg statusa za koje je vjerojatnije da nude više vrijednih informacija npr. vezanih za posao (Aguilera, 2002.; Reingold, 1999.). Primjer je prestižno zanimanje poslovnog kontakta, moć i utjecaj, povezanost s poduzećem i industrijskim sektorom (Boxman, de Graaf \& Flap, 1991.).

\section{ULOGA SOCIJALNOG KAPITALA U TRAŽENJU POSLA}

Teorije socijalnih mreža temelj su za općenitu pretpostavku o važnosti strukture i sastava socijalne mreže tražitelja posla u predviđanju strategija traženja posla, ali i njihovih ishoda - uspješnog zapošljavanja. Umrežavanje se može definirati kao posebna vrsta neformalnog ponašanja u traženju posla (Saks i Asliforth, 2000.), a definira se kao »ponašanje pojedinca usmjereno prema kontaktiranju prijatelja, poznanika i drugih ljudi s glavnom svrhom dobivanja informacija ili savjeta o dobivanju posla« (Wanberg i sur., 2000.). Neformalno je jer se ne oslanja na formalne posrednike, a sastoji se od kontaktiranja prijatelja, rođaka, poznanika, trenutnih ili bivših kolega i suradnika. S obzirom na fazu traženja posla (Blau, 1994., prema Saks i Ashforth, 2000.), umrežavanje može biti klasificirano kao faza planiranja ponašanja u procesu traženja posla.

Posebno je zanimljivo proučavati ulogu socijalnog kapitala prilikom traženja prvog zaposlenja jer su se brzina zapošljavanja i 
kvaliteta prvog posla pokazali kritičnima za predviđanje kasnijeg uspjeha u karijeri, mjerenog veličinom zarade i statusom posla (Gregg, 2001.; Richards, 1984.; Steffy i sur., 1989.). To postaje posebno važno u suvremenom kontekstu sve veće kompeticije na tržištu rada potaknutom smanjenom ponudom poslova te sve većim razlikama u plaći i statusu pojedinih sektora, zvanja i zanimanja (vidi Nestić, 2014.). Bowman (1987.) potragu za informacijama koju poduzimaju mladi diplomanti u postupku traženja prvog zaposlenja dijeli u dvije kategorije s obzirom na vrstu kanala koju koriste: prva su formalne informacije o ponudi poslova koje se javno objavljuju, a druga skrivene informacije o mogućnostima zapošljavanja koje se šire neformalnim putem. One u velikoj mjeri ovise o socijalnom kapitalu pojedinca, često određuju dostupnost i kvalitetu prvog zaposlenja pa su i temelj budućih individualnih razlika, ali i izvor društvene segregacije.

Socijalne mreže mladih nezaposlenih osoba koje iz obrazovnog sustava izlaze na tržište rada imaju nekoliko uporišta. S jedne strane, one počivaju na kontaktima njihove obitelji i roditelja koji su u pravilu još zaposleni u godinama nakon njihova izlaska iz školovanja. S druge strane, postoje kontakti iz lokalne zajednice u kojoj su odrasli. Konačno, oni su povezani kontaktima koje su stekli tijekom školovanja (tako je status aktera i broj kontakata koje pojedinac ima različit ovisno o pohađanom tipu i razini škole). Prema nekim autorima (de Witte i sur., 2013.), i socioekonomski status mladih ljudi operacionalizira se putem profesionalnog statusa roditelja, obrazovanja roditelja i statusa zaposlenosti roditelja.

Ratcliff i Bogdan (1988., prema Bjarnason i Sigurdardottir, 2003.) pokazali su da kod mladih nezaposlenih osoba roditeljska emocionalna podrška smanjuje stres, dok su savjeti povezani s povećanjem stresa vjerojatno zbog doživljaja pritiska da što prije nađu posao. Nezaposlene osobe čiji roditelji imaju rukovodeće funkcije imaju veću vjerojatnost korištenja umrežavanja prilikom traženja posla. Zbog mrežnog prijenosa, ove osobe mogu mobilizirati odnose svojih roditelja pri traženju posla (Delattre i Sabatier, 2007.). Roditelji višeg obrazovanja na vrijeme prenose djeci $\mathrm{i}$ informacije o obrazovanim prilikama putem vlastitih socijalnih mreža (Andres, 2007.). U početnoj fazi karijere, kontakti iz svijeta rada ili profesionalnih krugova relativno su rijetki (eventualno stečeni kroz praksu ili povremene poslove) te u pravilu još nisu razvijeni. Try (2005.) navodi da tzv. F-veze (eng. family, friends, firms) koje su sastavljene od obitelji, prijatelja i kolega mogu funkcionirati kao sustav razmjene ili servis za informacije koristan za diplomante u potrazi za poslom. Na primjer, ukoliko jedan ili oba roditelja imaju visok stupanj obrazovanja, oni su na istoj obrazovnoj razini s diplomantom i mogu imati pristup informacijama relevantnim za proces traženja posla. U svom istraživanju, Try (2005.) socijalni kapital nezaposlenih diplomanata mjeri obrazovanom razinom roditelja, obrazovnom razinom prijatelja $i$ prethodnim radnim iskustvom. Posljednje navedeno smatra bitnim za umrežavanje $\mathrm{s}$ poslodavcima i kolegama.

Kao što je i pretpostavio, Try (2005.) je utvrdio značajan utjecaj obrazovanja roditelja na korištenje neformalnih, ali ne i formalnih kanala traženja posla. Pritom je samo obrazovanje majke bilo značajan prediktor što je u skladu s predviđanjima da obrazovanje majke ima veći utjecaj na razvoj djeteta od obrazovanja oca (Try, 2005.). Obrazovna razina prijatelja/ susjeda je značajno predviđala intenzitet traženja posla neformalnim kanalima, putem socijalnih mreža, ali ne i traženje posla formalnim kanalima (javljanje na natječaje, 
slanje ponuda). S druge strane, prethodno radno iskustvo ili nije imalo utjecaja ili je imalo negativan utjecaj na korištenje neformalnih kontakata čime nije potvrđen značaj umrežavanja s kolegama kroz radno iskustvo (Try, 2005.).

$\mathrm{Na}$ stvaranje mreža može djelovati financijski status pojedinca što posebno dolazi do izražaja u ekonomski nestabilnim vremenima. Pojedinci s većim financijskim primanjima i manjim ekonomskim pritiscima mogu se osloniti na svoja primanja te vrijeme iskoristiti za umrežavanja i stvaranje uglavnom slabih veza. Nasuprot njima, osobe koje su pod ekonomskim pritiscima okružuju se osobama s kojima su povezani snažnim vezama (obitelj, prijatelji) kako bi primili podršku i osnažili vlastite resurse (Smith, 2000.). Nezaposlenost vodi k siromaštvu i socijalnoj izolaciji (Gore i Figueiredo, 1997.), te su fenomeni koji se međusobno potkrepljuju i vode k socijalnoj isključenosti (Gallie i sur., 2003.). Nezaposlene osobe nemaju dovoljno prilika upoznavati i redovito kontaktirati s osobama izvan vlastite obitelji (Jahoda, 1982.), a siromašni ne posjeduju dovoljno materijalnih resursa za različite oblike druženja koja su okvir za stvaranje novih (slabih) veza s drugim ljudima. Prema općeprihvaćenom Fryerovom modelu ograničenog djelovanja (prema Fryer i Payne, 1986.), nezaposlenost uz sebe veže prvenstveno psihološki destruktivno siromaštvo. U konačnici, socijalnu isključenost karakteriziraju malobrojne snažne veze s članovima obitelji, prijateljima i susjedima koji dijele isti nepovoljni socijalni status. Za takve pojedince najveći je izazov stvaranje većih i raznolikih socijalnih mreža te uspostavljanje kontakata s akterima drugačijeg socioekonomskog statusa.

Namjera ulaganja u umrežavanje ovisi o uvjetima na tržištu rada. Galeotti i Merlino (2014.) pokazali su da pojedinac neće puno ulagati u umrežavanje ukoliko je niska vjerojatnost gubitka posla ili velika vjerojatnost nenalaženja posla. Kada je niska vjerojatnost ne nalaženja posla, nema vrijednosti ulaganja u umrežavanje jer je nizak rizik gubitka ili nedobivanja posla. Ukoliko je velika vjerojatnost nenalaženja ili gubitka posla, niska je vrijednost ulaganja u umrežavanje jer je većina veza formirana s drugim tražiteljima posla i bit će velika kompeticija za dobivanje posla. Slična je veza između stope umrežavanja i stope nezaposlenosti. Kada je niska stopa nezaposlenosti, mreže kontakata za informacije o poslu nisu visoko povezane, što implicira nisku stopu umrežavanja. U ovom slučaju, povećanje stope nezaposlenosti povećava povezanost mreže i posljedično se vjerojatnost pronalaska posla putem mreže također povećava. Nadalje, kako stopa nezaposlenosti dalje raste, mreža postaje pretrpana tražiteljima posla što smanjuje stopu umrežavanja. Traženje posla putem umrežavanja je izričito naglašeno kada je umjerena stopa nezaposlenosti na tržištu rada. Može se prikazati oblikom povezanosti između stope nezaposlenosti i ulaganja u umrežavanje koji određuje »obrnuti U« oblik povezanosti između nezaposlenosti i vjerojatnosti da će pojedinac pronaći posao putem socijalnih kontakata.

Kao što je navedeno, različite karakteristike mreža $\mathrm{i}$ heterogenost kontakata $\mathrm{u}$ mreži mogu biti važni za sudjelovanje na tržištu rada i uspješno traženje posla, posebno mladih koji traže prvo zaposlenje i ne posjeduju radno iskustvo koje može biti relevantno poslodavcima. Osim toga, socijalni kontakti i podrška su krucijalni za integraciju potencijalno isključenih grupa, kao što su etničke manjine (Ooka i Wellman, 2005.), mladi (Holzer, 1988., prema Linsday, 2005.) i žene koje se vraćaju na radna mjesta (Chapple, 2002.). Visoka stopa nezaposlenosti među mladima pota- 
kla je brojna istraživanja psihosocijalnih i ekonomskih aspekata ovog fenomena, ali istraživanja uloge socijalnog kapitala definiranog kroz socijalnu umreženost i kontakte još uvijek su rijetka. Koliko nam je poznato, ovo je prvo istraživanje u Bosni i Hercegovini i susjednim zemljama koje se bavi karakteristikama socijalnih mreža mladih visokoobrazovanih osoba koje traže prvo zaposlenje. Dosadašnja istraživanja potvrdila su značajnu ulogu dostupnosti i kvalitete prvog zaposlenja u formiranju budućih individualnih razlika u socioekonomskom statusu članova nekog društva (Browman, 1987.). Povezanost doživljaja dostupnosti socijalnog kapitala u traženju prvog zaposlenja sa socioekonomskim značajkama pojedinca indikator je društvene segregacije te može upućivati na procese koji leže u podlozi ove segregacije te socijalne isključenosti pojedinca i skupina. Stoga je cilj rada bio ispitati sociodemografske prediktore socijalnog kapitala na koje se diplomanti mogu osloniti prilikom traženja zaposlenja. U fokusu interesa bili su:

a) veličina mreže - ukupan broj ljudi s kojima je pojedinac povezan

b) snaga povezanosti - bliskost društvenog odnosa između pojedinca i druge osobe u mreži (aktera)

c) status aktera - prestiž aktera temeljen na obrazovnom, ekonomskom i radnom statusu onih koji čine karijernu mrežu pojedinca.

Na temelju dosadašnjih spoznaja o formiranju individualnih socijalnih mreža, postavljene su sljedeće hipoteze o povezanosti socioekonomskih značajki pojedinca i karakteristika dostupne socijalne mreže prilikom traženja zaposlenja:

H1: Karakteristike individualnih socijalnih mreža koje predstavljaju resurs u procesu traženja prvog zaposlenja bit će povezane sa socioekonomskim značajka- ma osobe. $\left(\mathrm{H}_{1}\right)$ Viši socioekonomski status izražen kroz mjesečne prihode kućanstva, razinu obrazovanja roditelja i njihov radni status bit će pozitivno povezan s veličinom mreže pojedinca i statusom aktera $\mathrm{s}$ kojima je povezan. Diplomanti višeg socioekonomskog statusa bit će umreženi $\mathrm{s}$ više drugih pojedinaca te s osobama koje i same imaju bolji socioekonomski status. $\left(\mathrm{H}_{2}\right)$ Diplomanti nižeg socioekonomskog statusa bit će povezani snažnim, bliskim vezama kako bi primili podršku i osnažili vlastite resurse. Zato će mjesečni prihodi kućanstva, razina obrazovanja i radni status roditelja diplomanata biti negativno povezani sa snagom veza koje čine individualnu socijalnu mrežu diplomanata.

\section{METODA}

\section{Uzorak i postupak}

Istraživanje je provedeno na prigodnom uzorku iste generacije diplomanata javnih fakulteta u Bosni i Hercegovini, 2015. godine. Od ukupno 887 kontaktiranih diplomanata, odazvalo se njih 730 (82\%). U uzorku su najzastupljeniji diplomanti Filozofskog fakulteta (25\%), Fakulteta prirodoslovno-matematičkih i odgojnih znanosti (21\%) i Ekonomskog fakulteta (11\%). Zastupljenost diplomanata na ostalim studijima se kreće od 1\% (Fakultet političkih nauka, Fakultet za saobraćaj i komunikacije, Agronomski fakultet, Fakultet zdravstvenih studija) do 8\% (Pravni i Farmaceutski fakultet). Svi sudionici pohađali su zadnji semestar zadnje godine studija, od čega je njih 94\% $(\mathrm{N}=684)$ bilo u statusu redovnih studenata, a $6 \%$ izvanrednih $(\mathrm{N}=46)$. Svi su bili nezaposleni. Preko dvije trećine uzorka činile su žene $(\mathrm{N}=562 ; 77 \%)$, prosječna dob sudionika bila je 24 godine $(\mathrm{M}=24,36$; $\mathrm{sd}=2,49)$, a prosječna duljina studiranja 5 godina $(\mathrm{M}=5,28 ; \mathrm{sd}=0,85)$. Detaljniji opis uzorka nalazi se u tablicama 1. i 2. 
Tablica 1.

Opis uzorka: Prosječna mjesečna primanja u kućanstvu (KM-konvertibilne marke mjesečno*) $(N=730)$

\begin{tabular}{ll}
\hline & $\mathrm{N}(\%)$ \\
\hline Manje od 125 KM\%) & $66(9,04 \%)$ \\
$250-500 \mathrm{KM}$ & $220(30,14$ \\
$500-750 \mathrm{KM}$ & $143(19,59 \%)$ \\
$750-1000 \mathrm{KM}$ & $103(14,11 \%)$ \\
$1000-1250 \mathrm{KM}$ & $66(9,04 \%)$ \\
$1250-1500 \mathrm{KM}$ & $53(7,26 \%)$ \\
Iznad 1500 KM & $68(9,31 \%)$ \\
Neodgovoreno & $11(1,51 \%)$ \\
\hline
\end{tabular}

* jedna konvertibilna marka (KM) je 3,74 HRK ; *jedna konvertibilna marka (KM) je 0, 51 Eur

Tablica 2.

Opis uzorka: obrazovni i radni status roditelja diplomanata $(N=730)$

\begin{tabular}{|c|c|c|c|}
\hline & & Majka & Otac \\
\hline \multirow{7}{*}{ Razina obrazovanja } & $\begin{array}{l}\text { Nezavršena ili završena } \\
\text { osnovna škola }\end{array}$ & $70(9,59 \%)$ & $35(4,8 \%)$ \\
\hline & $\begin{array}{l}\text { Trogodišnja strukovna } \\
\text { škola }\end{array}$ & $133(18,22 \%)$ & $188(25,75 \%)$ \\
\hline & $\begin{array}{l}\text { Četverogodišnja škola ili } \\
\text { gimnazija }\end{array}$ & $306(42 \%)$ & $246(33,70 \%)$ \\
\hline & Viša škola & $65(8,9 \%)$ & $78(10,68 \%)$ \\
\hline & $\begin{array}{l}\text { Fakultet, visoka škola ili } \\
\text { akademija }\end{array}$ & $138(18,9 \%)$ & $151(20,68 \%)$ \\
\hline & $\begin{array}{l}\text { Poslijediplomsko } \\
\text { specijalističko ili } \\
\text { znanstveno obrazovanje }\end{array}$ & $15(2,05 \%)$ & $28(3,84 \%)$ \\
\hline & Nedostaje & $3(0,34 \%)$ & $4(0,55 \%)$ \\
\hline \multirow{4}{*}{ Radni status } & Zaposlen/-a & $371(50,7 \%)$ & $422(57,9 \%)$ \\
\hline & Nezaposlen/-a & $287(40 \%)$ & $73(10 \%)$ \\
\hline & Umirovljen/-a & $60(8,22 \%)$ & $201(27,53 \%)$ \\
\hline & Nedostaje & $12(1,08 \%)$ & $34(4,57 \%)$ \\
\hline
\end{tabular}

Podaci su prikupljani metodom online ankete. Prije individualnog kontaktiranja svakog od sudionika istraživanja, studentskim predstavnicima fakulteta i pojedinih studijskih grupa poslana je e-pošta s objašnjenjem svrhe istraživanja i zamolbom za prikupljanje kontakata (adresa e-pošte i/ ili brojeva mobitela) studenata, završne godine čiji su predstavnici. Potom je svakom od sudionika individualno na osobnu e-adresu poslana zamolba za sudjelovanje $u$ istraživanju. Istraživač se predstavio, podsjetio sudionika da je kontakt dobiven od student- skog predstavnika, objasnio cilj istraživanja te još jednom napomenuo sudioniku da je istraživanje anonimno i dobrovoljno. U svrhu poticanja što većeg odgovaranja, ispitanicima je naglašeno da sudjelovanjem u istraživanju sudjeluju i u nagradnoj igri u kojoj će tri slučajno odabrana sudionika biti nagrađena poklon bonom u iznosu 20KM (10 Eur). Po završetku istraživanja svi sudionici su bili obaviješteni o rezultatima nagradne igre, a dobitnicima su uručene nagrade. 
Za konstrukciju online upitnika korišten je Google Docs Survey servis. Sudionici su pristupali upitniku pritiskom na poveznicu koju su zajedno sa zamolbom za sudjelovanje u istraživanju dobili na osobne adrese e-pošte, a sama primjena trajala je 15-20 minuta. Onemogućena je opcija višestrukog ispunjavanja upitnika $\mathrm{s}$ iste e-adrese. Po završetku primjene upitnika, svi podaci automatski su se spremali u bazu podataka.

\section{Instrumenti}

Sociodemografski upitnik; konstruiran za potrebe ovog istraživanja, sadržavao je pitanja o dobi, spolu, nazivu fakulteta koji sudionik pohađa i studijske grupe ukoliko postoji, duljini studiranja, statusu studiranja (redovan / izvanredan student), stupnju obrazovanja roditelja (nezavršena ili završena osnovna škola / trogodišnja strukovna škola/ četverogodišnja škola ili gimnazija / viša škola / fakultet, visoka škola ili akademija / poslijediplomsko / specijalističko ili znanstveno obrazovanje), statusu zaposlenja roditelja (zaposlen / nezaposlen / umirovljen) i prosječnim materijalnim primanjima u obitelji (suma prihoda svih članova kućanstva podijeljena $\mathrm{s}$ brojem članova kućanstva).

Skala karakteristika socijalne mreže (van Hoye i sur., 2009.): sadrži 10 čestica na koje se odgovara na 5-stupanjskoj skali ( 1 = uopće se ne slažem; $5=$ potpuno se slažem). Validacija skale na $\mathrm{BiH}$ uzorku ukazuje na trofaktorsku strukturu (veličina mreže, snaga veze i status aktera) pri čemu je visoka pouzdanost za pojedine faktore i kreće se u rasponu od $\alpha=0,76$ (veličina mreže) do $\alpha=0,81$ (status aktera). Faktori i pripadajuće čestice: 1 . faktor veličina mreže (»Poznajem velik broj ljudi koji bi mogli pomoći u pronalaženju posla." »Imam kontakte s kojima mogu razgovarati da mi pomognu pronaći posao. « »Poznajem malo ljudi koji bi mogli pomoći u traženju zaposlenja." "Mogu se osloniti puno na svoje rodbine, prijatelja ili poznanika za informacije o poslu.« ); 2. faktor - snaga povezanosti (»Većina ljudi koja bi mi mogla pomoći pronaći posao su ljudi koje dobro poznajem, kao što su moja obitelj ili prijatelji." »Većina ljudi koja bi mi mogla pomoći pronaći posao su ljudi s kojima često razgovaram «. »Većina ljudi koja bi mi mogla pomoći pronaći posao su ljudi s kojima se osjećam ugodno kada razgovaram, čak $i$ o 'osjetljivim' temama. «); 3. faktor - status aktera (»Većini ljudi koji bi mi mogla pomoći pronaći posao općenito ide dobro u životu. " "Većina ljudi koji bi mi mogli pomoći pronaći posao i sami imaju dobar posao. » "Većina ljudi koji bi mi mogli pomoći pronaći posao su dobro obrazovani.«).

\section{Analiza podataka}

Prije obrade rezultata KolmogorovSmirnovljevim testom normaliteta distribucije (tablica 3.) pokazano je kako varijable veličina mreže, snaga veze i status veze značajno odstupaju od normalne raspodjele. Daljnim pregledom distribucija, pokazateljima asimetričnosti (eng. skewness) i spljoštenosti (eng. kurtosis) distribucije utvrđeno je kako odstupanja rezultata nisu velika (asimetričnost za veličinu mreže iznosi $-0,52$, za snagu povezanosti 0,01 i status veze aktera $-0,33$, a spljoštenost za veličinu mreže iznosi 0,41 , snagu povezanosti $-0,89$ i status veze $-0,27)$ te su se $u$ svrhu odgovora na postavljene istraživačke probleme primijenili parametrijski postupci obrade podataka Pearsonovi koeficijenti korelacija i linearna regresijska analiza za utvrđivanje povezanosti karakteristika mreže i sociodemografskih značajki pojedinca. 
Tablica 3.

Osnovni deskriptivni pokazatelji karakteristika socijalne mreže (veličina mreže, snaga veze $i$ status aktera) diplomanata i rezultati Kolmogorov-Smirnovljevog testa za mjerene varijable $(N=730)$

\begin{tabular}{ccccc}
\hline & $\mathrm{M}$ & $\mathrm{sd}$ & $\mathrm{TR}$ & $\mathrm{K}-\mathrm{S} z$ \\
\hline Veličina mreže & 11,17 & 2,20 & $4-20$ & $0,090^{\text {** }}$ \\
\hline Snaga veze & 8,98 & 2,01 & $3-15$ & $0,128^{\star *}$ \\
\hline Status aktera & 10,47 & 2,69 & $3-15$ & $0,130^{\text {** }}$ \\
\hline
\end{tabular}

\section{Legenda:}

$\mathrm{M}$ - aritmetička sredina

sd - standardna devijacija

TR - teoretski raspon

K-S z - rezultati Kolmogorov Smirnovljeva testa

\section{REZULTATI}

Iz matrice bivarijatnih korelacija (Tablica 4.) vidljivo je da su korelacije između ispitivanih varijabli niske ili neznačajne. Postoji značajna pozitivna povezanost $u$ procjenama različitih dimenzija karijerne umreženosti - veličine mreže, snage veza i statusa aktera. Međutim, povezanosti su niske i iznose od 0,093 između statusa aktera i snaga veze, do 0,364 između veličine mreže i statusa aktera. Ove niske korelacije između pojedinih dimenzija karijerne umreženosti, govore u prilog multidimenzionalne definicije ove vrste socijalnog kapitala.

Tablica 4.

Pearsonovi koeficijenti korelacija između samoprocjena karakteristika socijalne mreže diplomanata i sociodemografskih varijabli

\begin{tabular}{|c|c|c|c|c|c|c|c|c|}
\hline & \multicolumn{8}{|c|}{ Uzorak $(\mathrm{N}=730)$} \\
\hline & 1 & 2 & 3 & 4 & 5 & 6 & 7 & 8 \\
\hline 1. Veličina mreže & 1 & $0,283^{* *}$ & $0,364^{* *}$ & $0,074^{*}$ & 0,000 & 0,059 & 0,005 & $0,179^{\text {** }}$ \\
\hline 2. Snaga veze & & 1 & $0,093^{* *}$ & 0,021 & 0,005 & $-0,028$ & 0,015 & 0,008 \\
\hline 3. Status veze & & & 1 & $0,111^{* *}$ & $0,106^{\star *}$ & $0,082^{*}$ & $0,079^{*}$ & $0,112^{* *}$ \\
\hline 4. Obrazovanje oca & & & & 1 & $0,389^{* *}$ & $-0,068$ & 0,028 & $0,124^{* *}$ \\
\hline 5. Obrazovanje majke & & & & & 1 & $-0,060$ & $0,088^{*}$ & $0,159^{* *}$ \\
\hline 6. Zaposlenost oca & & & & & & 1 & 0,074 & $-0,053$ \\
\hline 7. Zaposlenost majke & & & & & & & 1 & 0,038 \\
\hline $\begin{array}{l}\text { 8. Prosječna primanja u } \\
\text { obitelji }\end{array}$ & & & & & & & & 1 \\
\hline
\end{tabular}


Prosječna primanja u obitelji pozitivno su povezana s veličinom mreže i statusom aktera te razinom obrazovanja oba roditelja, a negativno s radnim statusom oca. Očekivano, viši i povoljniji socioekonomski status pozitivno je povezan s karijernim socijalnim kapitalom. Snaga veza nije značajno povezana $\mathrm{s}$ istraživanim socioekonomskim značajkama diplomanata. Kako bi utvrdili doprinos sociodemografskih varijabli u objašnjavanju individualnih razlika u pojedinim dimenzijama karijernog socijalnog kapitala diplomanata, provedene su linearne regresijske analize pri čemu su veličina veze, snaga veza i status aktera predstavljali kriterijske varijable, a individualne sociodemografske značajke prediktorske varijable.

Tablica 5.

Rezultati regresijskih analiza za kriterije: veličina mreže, snaga veza, i status aktera $(N=730)$

\begin{tabular}{lccc}
\hline \multirow{2}{*}{ Prediktori } & \multicolumn{3}{c}{ Kriterij } \\
\cline { 2 - 3 } & Veličina mreže & Snaga veze & Status aktera \\
\cline { 2 - 3 } & Beta $(\beta)$ & Beta $(\beta)$ & Beta $(\beta)$ \\
\hline Obrazovanje oca & 0,071 & 0,021 & 0,078 \\
\hline Obrazovanje majke & $-0,048$ & $-0,022$ & 0,061 \\
\hline Zaposlenost oca & 0,055 & $-0,035$ & $0,084^{*}$ \\
\hline Zaposlenost majke & $-0,010$ & 0,023 & 0,075 \\
\hline Prosječna primanja u kućanstvu & $0,168^{* *}$ & 0,008 & $0,100^{* *}$ \\
\hline Kor. $R^{2}$ & $0,187^{* *}$ & 0,047 & $0,203^{* *}$ \\
\hline
\end{tabular}

Legenda:

Beta $(\beta)$ - vrijednost standardiziranog regresijskog koeficijenta

$R$ - koeficijent multiple korelacije

Korigirani $R^{2}$ - korigirani ukupni doprinos objašnjenoj varijanci

$* p<0,05, * * p<0,01$

Socioekonomske varijable objašnjavaju $2,8 \%$ varijance individualnih razlika u procjeni veličine mreže. Značajni samostalni prediktor su prosječna mjesečna primanja u kućanstvu $(\beta=0,168 ; t(730)=4,375 ; p$ $<0,01)$, što znači da diplomanti višeg financijskog statusa poznaju veći broj ljudi koji bi im mogli pomoći u traženju zaposlenja.

Socioekonomske varijable objašnjavaju 3,4\% varijance procjena statusa aktera. Značajni samostalni prediktori su radni sta- tus oca $(\beta=0,027 ; t(730)=2,217 ; p<0,01)$ i prosječna primanja u kućanstvu $(\beta=0,1$; $t(730)=2,622 ; p<0,01)$. Diplomanti čiji je otac zaposlen umreženi su s pojedincima višeg statusa, kao i oni koji imaju viša mjesečna primanja.

Konačno, socioekonomske značajke nisu se pokazale značajnim prediktorom snage veza, odnosno stupnja bliskosti s osobama koje bi mogle pomoći u traženju zaposlenja. 


\section{RASPRAVA}

Provedeno istraživanje imalo je za cilj istražiti socioekonomske prediktore individualnih razlika u socijalnom kapitalu diplomanata na koji se oni mogu osloniti prilikom traženja prvog zaposlenja. Ovaj socijalni kapital definiran je kroz individualnu percepciju umreženosti s drugima, a poseban predmet interesa bili su - veličina socijalne mreže, status aktera s kojima je pojedinac povezan te snaga socijalnih veza s drugima. Razlike u socijalnim mrežama trebale bi igrati značajnu ulogu u pozicioniranju diplomanata na tržištu rada te razvoju njihove buduće karijere, a njihova povezanost sa socioekonomskim značajkama pojedinca daje uvid u moguće procese društvene segregacije te procese kojima početne socioekonomske razlike među pojedincima komparabilnih profesionalnih karakteristika stvaraju razlike u njihovom karijernom razvoju.

Pozitivne i značajne bivarijatne korelacije između samoprocjena različitih indikatora individualnog socijalnog kapitala - između veličine mreže i snage veze $(r=0,283$; $\mathrm{p}<0,01)$ ukazuju na mogućnost postojanja faktora drugog reda koji opisuju ove dvije karakteristike socijalnih mreža. Veličina mreže i snaga veza čine formalnu strukturu odnosa ili veza koje čine mrežu (Adler i Kwon, 2002.). Što je veličina mreže ili ukupan broj ljudi s kojima je pojedinac povezan veći (Seibert, Kraimer i Liden, 2001.), vjerojatnije je da će pojedinac dobiti informaciju relevantnu za statusni i prihodni napredak (Campbell, Marsden i Hurlbert, 1986.). Utvrđena značajna povezanost između samoprocjena veličine mreže i snage uspostavljenih veza govori u prilog činjenici da su snažne veze obično više dostupne nego slabe veze i rezultiraju češćim interakcijama, čime se povećava vjerojatnost dobivanja informacija (Reingen i Kernan,
1986.). U tom smislu, istraživanja su pokazala da ljudi imaju veću vjerojatnost umrežavanja sa snažnim vezama nego sa slabim vezama prilikom prikupljanja informacija (Brown i Reingen, 1987.; Gilly, Graham, Wolfinbarger i Yale, 1998.) što može biti osobito izraženo kod diplomanata prilikom prikupljanja informacija o slobodnim radnim mjestima. Pojedinci iz njihove okoline s kojima imaju češće interakcije i koji predstavljaju snažne veze poput roditelja, prijatelja i obitelji su ujedno i osobe koje su višeg statusa, pa je za njih i vjerojatnije da nude više vrijednih informacija vezanih uz tržište rada i mogućnosti zapošljavanja (Aguilera, 2002.; Reingold, 1999.).

Šverko, Galić i Maslić Seršić (2005.) su longitudinalnim praćenjem reprezentativnog uzorka nezaposlenih osoba u Hrvatskoj utvrdili kako stupanj subjektivne socijalne izolacije raste $\mathrm{u}$ funkciji trajanja nezaposlenosti (nakon godine dana), odnosno pada sa zapošljavanjem. Međutim, razlike su bile značajne već u prvoj točki mjerenja, u trenutku kada su obje skupine bile nezaposlene. Ovaj nalaz govori u prilog važnosti socijalnog kapitala u predviđanju uspješnosti nalaženja zaposlenja te o pogubnom procesu socijalne deprivacije $\mathrm{i}$ isključenosti koju sa sobom donosi produljena nezaposlenost. Mlade visokoobrazovane osobe koje traže prvo zaposlenje donose na tržište rada različiti karijereni socijalni kapital. Prema rezultatima našeg istraživanja, ove razlike predviđa socioekonomski status diplomanata, prvenstveno financijska primanja u kućanstvu te razina obrazovanja i radni status roditelja. Dakle, diplomanti višeg socioekonomskog statusa, zahvaljujući socijalnom kapitalu, svoj povoljniji položaj u društvu mogu još više osnažiti brzim pronalaženjem zaposlenja. Drugim riječima, početne razlike koje nisu velike, mogu se na tržištu rada povećavati. Delattre i Sabatier (2007.) utvrdili su da su 
diplomanti čiji su očevi zaposleni umreženi s osobama višeg statusa i da zbog toga imaju veću vjerojatnost umrežavanja prilikom traženja posla. Prema rezultatima dosadašnjih istraživanja, roditelji višeg obrazovanja na vrijeme prenose djeci i informacije o karijernim prilikama putem vlastitih socijalnih mreža (Anders, 2007.). Diplomanti s većim mjesečnim primanjima imaju šire mreže što ide u prilog činjenici da na stvaranje veza može djelovati financijski status pojedinca koji je izraženiji u ekonomski nestabilnijim vremenima. Prema Smithu (2000.), pojedinci s većim financijskim primanjima i manjim ekonomskim pritiscima se mogu osloniti na svoja primanja te vrijeme iskoristiti za umrežavanja i stvaranje uglavnom slabih veza. Dobiveni rezultati u skladu su s istraživanjem Try (2005.) koji je utvrdio značajan utjecaj obrazovanja roditelja na korištenje neformalnih, ali ne i formalnih metoda traženja posla. U našem istraživanju, socio-demografske značajke diplomanata nisu bile značajni prediktori samoprocjena snaga veza, odnosno procjena stupnja bliskosti s osobama koje mogu pomoći u traženju posla. Osim toga, iako značajan, udio objašnjene varijance individualnih razlika u socijalnom kapitalu vrlo je mali i iznosi oko 3\%. Niska povezanost varijabli sociodemografskog statusa s karijernim socijalnim kapitalom pojedinca govori u prilog niske segregacije društva što je svakako važan resurs ekonomskog napretka. No, ovaj nalaz trebalo bi potkrijepiti longitudinalnim praćenjem uspjeha diplomanata na tržištu rada. Osim toga, ovi su nalazi prikupljeni na relativno homogenom uzorku mladih visokoobrazovanih osoba koje su već prošle nekoliko velikih selekcijskih događaja - završetak srednje škole, upis na fakultet $i$, na kraju, uspješan završetak studija.

Važno je napraviti distinkciju između mobiliziranog socijalnog kapitala koji se vezuje uz kontakte korištene pri traženju posla (Lin, 1999.) i dostupnog socijalnog kapitala koji se odnosi na cjelokupnu karijernu socijalnu mrežu u koju je pojedinac uključen. Zato bi bilo važno istražiti u kojoj se mjeri mlade osobe zapošljavaju koristeći svoj socijalni kapital: koliko su s kvalitetom zaposlenja i brzinom zapošljavanja povezane različite dimenzije umreženosti; koliko je važna veličina mreže, koliko status aktera, a koliko snaga veza? Istraživanje provedeno u Švedskoj pokazalo je da je veličina mreže pozitivno povezana $s$ uspješnim pronalaženjem zaposlenja dok snaga veza nije igrala značajnu ulogu (Korpi, 2001.). Međutim, ove nalaze ne možemo generalizirati na naše kulturalne i ekonomske uvjete. Primjerice, također u Švedskoj, Hällsten, Edling i Rydgren (2017.) su uspoređujući tri populacije mladih - dvije koje imaju imigrantsko podrijetlo (iransko ili iz zemalja bivše Jugoslavije) te mlade Šveđane koji nemaju imigrantsko podrijetlo, utvrdili da je karijerna socijalna umreženost najsnažniji prediktor zaposlenosti upravo među imigrantima iz zemalja bivše Jugoslavije.

Provedeno istraživanje otvara pitanje uloge socijalnog kapitala u karijernom uspjehu pojedinca, ali i razlika koje postoje unutar homogenih skupina po stupnju obrazovanja i radnom iskustvu te, u konačnici, podrijetla tih razlika - koliko su one pod kontrolom pojedinca i zajednice, a koliko »naslijeđen imetak« na koji malo možemo utjecati. S obzirom na dobivene rezultate $u$ kojima su prosječna materijalna primanja značajan prediktor veličine karijerne mreže i statusa veze u mreži, rezultati impliciraju da bi potencijalno ugrožene skupine mogle biti visokoobrazovane osobe nižih primanja.

Iako naši rezultati mogu biti relevantni za ispitivanje individualnih razlika u dostupnosti karijernog socijalnog kapitala i 
njegove povezanosti sa socioekonomskim značajkama osobe, a mogu imati i implikacije na zaključke o stupnju segregiranosti nekog društva po dimenziji socioekonomskog statusa, nekoliko metodoloških ograničenja provedenog istraživanja umanjuje sigurnost zaključaka. Ograničenja se prvenstveno odnose na prigodan uzorak te podzastupljenost muškaraca. Nadalje, u budućim istraživanjima trebalo bi longitudinalno pratiti diplomante te ispitati utjecaj dostupnog socijalnog kapitala na brzinu i kvalitetu zapošljavanja te daljnji uspjeh u karijeri.

\section{LITERATURA}

Adler, P. S., \& Kwon, S.W. (2002). Social capital: Prospects for a new concept. Academy of Management Review, 27(1), 17-40. https://doi. org/10.5465/amr.2002.5922314

Aguilera, M. B. (2002). The impact of social capital on labor force participation: Evidence from the 2000 Social Capital Benchmark Survey. Social Science Quarterly, 83(3), 853-874. https://doi.org/10.1111/1540-6237.00118

Andres, L., Adamuti-Trache, M., Yoon, E. S., Pidgeon, M., \& Thomsen, J. P. (2007). Educational expectations, parental social class, gender, and postsecondary attainment: A 10-year perspective. Youth \& Society, 39(2), 135-163. https://doi.org/10.1177/0044118X06296704

Bjarnason, T., \& Sigurdardottir, T. J. (2003). Psychological distress during unemployment and beyond: Social support and material deprivation among youth in six northern European countries. Social Science \& Medicine, 56(5), 973-985. https://doi.org/10.1016/S02779536(02)00109-0

Borgatti, S. P., \& Foster, P. C. (2003). The network paradigm in organizational research: A review and typology. Journal of Management, 29(6), 991-1013. https://doi.org/10.1016/S01492063(03)00087-4

Bowman, W. R. (1987). How college graduates find good jobs. Journal of College Placement, 47, 32-36.
Boxman, E. A. W., De Graaf, P. M., \& Flap, H. D. (1991). The impact of social and human capital on the income attainment of Dutch managers. Social Networks, 13(1), 51-73. https:// doi.org/10.1016/0378-8733(91)90013-J

Brown, J. J., \& Reingen, P. H. (1987). Social ties and word-of-mouth referral behavior. Journal of Consumer Research, 14(3), 350-362. https://doi.org/10.1086/209118

Campbell, K. E., Marsden, P. V., \& Hurlbert, J. S. (1986). Social resources and socioeconomic status. Social Networks, 8(1), 97-117. https:// doi.org/10.1016/S0378-8733(86)80017-X

Chapple, K. (2002). Out of touch, out of bounds: How social networks shape the labour market radii of women on welfare. Urban Geography, 22(7), 617-640. https://doi.org/10.2747/02723638.22.7.617

Coleman, J. (1990). Foundations of Social Theory. Cambridge: Harvard University Press.

Delattre, D., \& Sabatier, M. (2007). Social capital and wages: An econometric evaluation of social networking's effects. Labour, 21(2), 209-236. https://doi.org/10.1111/j.14679914.2007.00372.x

De Witte, K., Cabus, S., Thyssen, G., Groot, W., \& van den Brink, H. M. (2013). A critical review of the literature on school drop out. Educational Research Review, 10, 13-28. https://doi. org/10.1016/j.edurev.2013.05.002

Fryrer, D., \& Payne, R. (1986). Being unemployed: A review of the literature on the psychological experience of unemployment. In C. L. Cooper \& I. T. Robertson (Eds.), International Review of Industrial and Organizational psychology (pp. 235-278). Chichester: Wiley.

Galeotti, A., \& Merlino, L. P. (2014). Endogenous job contact networks. International economic review, 55(4), 1201-1226. https://oi. org/10.1111/iere. 12087

Gallie, D., Paugam, S., \& Jacobs, S. (2003). Unemployment, poverty and social isolation. Is there a vicious circle of social exclusion? European Societies, 5(1), 1-31. https://doi. org/10.1080/1461669032000057668

Gilly, M. C., Graham, J. L., Wolfinbarger, M. F., \& Yale, L. J. (1998). A dyadic study of interpersonal information search. Journal of the Academy of Marketing Science, 26(2), 83-100. https://doi.org/10.1177/0092070398262001 
Goldin C. (2016). Human Capital. In C. Diebolt \& M. Haupert (Eds.), Handbook of Cliometrics (pp. 55-86). Heidelberg: Springer Verlag.

Gore, C., \& Figueiredo, J. B. (Eds.). (1997). Social exclusion and anti-poverty policy: a debate. International Institute for Labour Studies Research and United Nations Development Programme Research Series, 110. Geneva: International Labour Organisation publications.

Granovetter, M. S. (1973). The strength of weak ties. American Journal of Sociology, 78(6), 1360-1380. https://doi.org/10.1086/225469

Granovetter, M. S. (1974). Getting a job: A study of contacts and careers. Cambridge: Harvard University Press.

Granovetter, M. S. (1995). Getting a job: A study of contacts and careers ( 2 nd ed). Chicago: University of Chicago Press.

Gregg, P. (2001). The impact of youth unemployment on adult unemployment in the NCDS. Economic Journal, 111(475), 626-653. https://doi.org/10.1111/1468-0297.00666

Hällsten, M., Edling, C., \& Rydgren, J. (2017). Social capital, friendship networks, and youth unemployment. Social Science Research, 61, 234-250. https://doi.org/10.1016/j.ssresearch.2016.06.017

Hobfoll, S. E. (1985). Personal and social resources and the ecology of stress resistance. In P. Shaver (Ed.), Review of personality and social psychology (pp. 265-290). Beverly Hills: Sage.

Jahoda, M. (1982). Employment and unemployment: A social-psychological analysis. Cambridge: Cambridge University Press.

Kwon, S.-W., \& Adler, P. S. (2014). Social capital: Maturation of a field of research. Academy of Management Review, 39(4), 412-422. https:// doi.org/10.5465/amr.2014.0210

Lin, N. (1999). Social networks and status attainment. Annual Review of Sociology, 25, 467-487. https://doi.org/10.1146/annurev. soc. 25.1 .467

Lindsay, C., Greig, M., \& McQuaid, R. W. (2005). Alternative job search strategies in remote rural and peri-urban labour markets: The role of social networks. Sociologia Ruralis, 45(1-2), 53-70. https://doi.org/10.1111/j.14679523.2005.00290.x
Marsden, P. V., \& Campbell, K. E. (1984). Measuring tie strength. Social Forces, 63(2), 482501. https://doi.org/10.1093/sf/63.2.482

Mouw, T. (2003). Social capital and finding a job: Do contacts matter?. American Sociological Review, 68(6), 868-898. https://doi. org/10.2307/1519749

Ooka, E., \& B. Wellman (2005). Does social capital pay off more within or between ethnic groups? Analyzing job searchers in five Toronto ethnic groups. In E. Fong (Ed.), Inside the Mosaic. Toronto: University of Toronto Press.

Reingen, P. H., \& Kernan, J. B. (1986). Analysis of referral networks in marketing: Methods and illustration. Journal of Marketing Research, 23(4), 370-378. https://doi. org/10.2307/3151813

Reingold, D. A. (1999). Social networks and the employment problem of the urban poor. Urban Studies, 36(11), 1907-1932. https://doi. org/10.1080/0042098992674

Saks, A. M., \& Ashforth, B. E. (2000). Change in job search behaviors and employment outcomes. Journal of Vocational Behavior, 56(2), 277-287. https://doi.org/10.1006/ jvbe.1999.1714

Seibert, S. E., Kraimer, M. L., \& Liden, R. C. (2001). A social capital theory of career success. The Academy of Management Journal, 44(2), 219-237. https://www.jstor.org/stable/3069452

Smith. S. S. (2000). Mobilizing social resources: Race, ethnic, and gender differences in social capital and persisting wage inequalities. The Sociological Quarterly, 41(4), 509-537. https://doi.org/10.1111/j.1533-8525.2000. tb00071.x

Steffy, B. D., Shaw, K. N., \& Noe, A. W. (1989). Antecedents and consequences of job search behaviors. Journal of Vocational Behavior, 35(3), 254-269. https://doi.org/10.1016/00018791(89)90029-8

Šverko, B., Galić, Z., \& Maslić Seršić, D. (2005). Nezaposlenost i socijalna isključenost: longitudinalna studija. Revija za socijalnu politiku, 13(1), 1-14. https://doi.org/10.3935/rsp. v13i1.417 
Try, S. (2005). The use of job search strategies among university graduates. The Journal of Socio-Economics, 34(2), 223-243. https://doi. org/10.1016/j.socec.2004.09.009

Van Hoye, G., Van Hooft, E., \& Ghent, F. L. (2009). Networking as a job search behaviour: A social network perspective. Journal of Occupational and Organizational Psychology, 82(3), 661-682. https://doi. org/10.1348/096317908X360675
Wanberg, C. R., Kanfer, R., \& Banas, J. T. (2000). Predictors and outcomes of networking intensity among unemployed job seekers. Journal of Applied Psychology, 85(4), 491-503. https:// doi.org/10.1037/0021-9010.85.4.491 


\title{
Summary
}

\section{AVAILABILITY OF SOCIAL CAPITAL UPON FIRST JOB SEARCH OF UNIVERSITY GRADUATES WITH DIFFERENT SOCIOECONOMIC STATUS}

\author{
Ivona Čarapina Zovko \\ The Faculty of Humanities and Social Sciences, University of Mostar \\ Mostar, Bosnia and Herzegovina \\ Darja Maslić Seršić \\ Department of Psychology, Faculty of Humanities and Social Sciences, University of \\ Zagreb \\ Zagreb, Croatia
}

The aim of the research was to analyze socio-demographic predictors of social networ$k s$ that university graduates can rely on while seeking their first employment-assessment of their size, strength of social connections and status of network participants. The network size is defined as an overall number of people an individual is connected with, and the network strength as a closeness of social relation between an individual and other persons in the network. Close friends and relatives are examples of strong ties, while rarely contacted acquaintances represent weak ties that are socially, economically and frequently physically distant. The status of a participant is operationalised as an educational, employment and economic status of those who form the individual's network. The research was conducted on a sample of 730 university graduates of public institutions of higher education in Bosnia and Herzegovina. The data were gathered through an online survey and are based on self-assessment. It has been determined that the individual's status predicts their assessment of their own social network: average salary is a positive independent predictor of the network's size, while average salary and father's employment status are positive predictors of the network participant's status that university graduates can rely on while seeking their first employment. The researched socioeconomic characteristics of university graduates explain between $2.8 \%$ and $3.45 \%$ of variances due to individual differences in the experience of social capital. The analyzed socioeconomic characteristics of university graduates were not connected with the experience of the strength of ties that form a social network.

Key words: university graduates, social networks, social capital, socioeconomic characteristics of individuals, job-seeking. 